\title{
MENINGKATKAN HASIL BELAJAR PESERTA DIDIK TENTANG MEDAN MAGNETIK PADA MATA PELAJARAN FISIKA DENGAN MENGGUNAKAN MODEL PEMBELAJARAN KOOPERATIF TIPE PICTURE AND PICTURE DI KELAS XI EB SMK NEGERI 2 KOTA BOGOR
}

\author{
Sri Lestari \\ SMK Negeri 2 Kota Bogor \\ Jalan Pangeran Sogiri No. 404 Tanah Baru - Bogor Utara \\ srilestarismkn2@gmail.com
}

\begin{abstract}
Abstrak: Penelitian ini diawali dengan adanya fenomena yang terjadi di kelas bahwa mata pelajaran fisika masih dianggap sebagai mata pelajaran yang sulit. Kemudian, hal ini berdampak kepada hasil belajar peserta didik yang masih berada
\end{abstract} di bawah standar KKM yang telah dibuat.

Penelitian ini bertujuan untuk: 1) untuk mengetahui model pembelajaran kooperatif Type Picture and Picture dapat meningkatkan hasil belajar peserta didik tentang medan magnet di Kelas XI EB semester 4 Tahun Pelajaran 2105-2016 SMK Negeri 2 Kota Bogor; 2) untuk mendeskripsikan proses peningkatkan hasil belajar peserta didik tentang medan magnet sebelum dan sesudah menggunakan model pembelajaran kooperatif Type Picture and Picture di Kelas XI EB semester 4 Tahun Pelajaran 2105-2016 SMK Negeri 2 Kota Bogor; dan 3) untuk

mengukur besarnya peningkatan hasil belajar peserta didik tentang medan magnet setelah menggunakan menggunakan model pembelajaran kooperatif Type Picture and Picture di Kelas XI EB semester 4 Tahun Pelajaran 2105-2016 SMK Negeri 2 Kota Bogor.

Bedasarkan hasil penelitian yang telah dilakukan di SMK Negeri 2 Bogor pada peserta didik kelas XI EB Semester 4 tahun pelajaran 2015 - 2016 bahwa: 1) Model pembelajaran Type Picture and Picture dapat meningkatan hasil belajar peserta didik pada tentang Medan Magnet di kelas XI EB SMK Negeri 2 Bogor dengan menggunakan model pembelajaran Type Picture and Picture; 2) Penggunaan model pembelajaran Type Picture and Picture membuat peserta didik tidak bosan dan jenuh sebaliknya merasa senang sehingga aktivitas belajar mereka meningkat. Hal ini terbukti pada siklus I ada 55,55\% atau 20 peserta didik yang aktif, 22,22\% atau 8 peserta didik yang cukup aktif dan 22,22\% atau 8 peserta didik yang kurang aktif pada saat pembelajaran. Setelah guru memperbaiki hasil refleksi pada siklus I maka pada siklus II didapat $77,77 \%$ atau 28 peserta didik aktif pada saat pembelajaran dan $22,22 \%$ atau 8 peserta tidak yang cukup aktif pada saat pembelajaran serta $0,00 \%$ atau tidak ada peserta didik yang tidak aktif pada saat pembelajaran. Hal tersebut berpengaruh terhadap hasil belajar yang dicapai peserta didik; dan 3) Hasil belajar mata pelajaran Fisika khususnya tentang Medan Magnet di kelas XI EB di SMK Negeri 2 Bogor sebelum menggunakan model pembelajaran Type Picture and Picture mempunyai nilai rata-rata 70. Pada saat pembelajaran diubah menggunakan model pembelajaran Type Picture and Picture, rata-rata hasil belajar peserta didik meningkat menjadi 75,56 pada siklus I dan 82,78 pada siklus II. 
Kata Kunci: Model Pembelajaran Kooperatif, Picture and Picture, Mata Pelajaran Fisika Materi Medan Magnet.

\section{PENDAHULUAN}

\section{A. Latar Belakang}

Keanekaragaman kemampuan peserta didik khususnya dalam mata pelajaran Fisika di SMK Negeri 2 Bogor sangat bervariasi. Kemampuan ini menyangkut kemampuan untuk mengingat kembali, memahami, menginterprestasi informasi, memahami makna simbol dan memanipulasinya, mengabstraksi, menggeneralisasi, menalar, memecahkan masalah dan yang lainnya. Sikap dan perilaku peserta didik pun beraneka ragam, baik dalam menanggapi pembelajaran pada umumnya maupun fisika pada khususnya. Survei yang peneliti lakukan terhadap peserta didik, memperlihatkan bahwa antusiasme dalam belajar fisika masih rendah. Mata pelajaran fisika masih dianggap sebagai mata pelajaran yang sulit. Kemudian, hal ini berdampak kepada hasil belajar peserta didik yang masih berada di bawah standar KKM yang telah dibuat.

Kenyataan di lapangan setelah dilakukan tes awal tentang Medan Magnet KKM yang telah ditentukan 75 setelah dilaksanakan analisis peserta didik yang mendapatkan nilai di atas KKM 11 orang (39\%) di bawah KKM 17 orang $(61 \%)$ dengan niai rata-rata kelas 64 Hal ini disebabkan ketika pembelajaran Medan Magnet guru mengajarnya masih konvensional, metode yang sering digunakan ceramah yang mengakibatkan peserta didik bosan dan tidak memiliki gairah belajar. Selain itu suasana dan pengorganisasian kelas sangat monoton, komunikasi pembelajaran hanya satu arah. Oleh karena itu guru akan memperbaiki pembelajaran tentang Medan Magnet dengan menggunakan model pembelajaran kooperatif type Picture and Picture.

Dalam proses pembelajaran terdapat beberapa istilah yang hampir sama, misalnya hasil belajar atau prestasi belajar. Dalam penelitian ini peneliti menekankan pada prestasi belajar. Prestasi belajar berasal dari kata "prestasi” dan "belajar" prestasi berarti hasil yang telah dicapai (Depdiknas 2007: 895). Menurut Senjaya (2011: 1) menjelaskanan bahwa prestasi belajar adalah sebuah kalimat yang terdiri dari dua kata, yakni "prestasi" dan "belajar", 
mempunyai arti yang berbeda. Untuk memahami lebih jauh tentang pengertian prestasi belajar, peneliti menjabarkan makna dari kedua kata tersebut. Senjaya (2001: 1) prestasi adalah suatu kegiatan yang telah dikerjakan, diciptakan baik secara individual atau kelompok. Sedangkan Saiful Bahri Djamarah, yang mengutip dari Mas'ud Hasan Abdul Qahar, dalam Senjaya (2011: 1) bahwa prestasi adalah apa yang telah dapat diciptakan, hasil pekerjaan, hasil yang menyenangkan hati yang diperoleh dengan jalan keuletan kerja.

Nasrun Harahap, dalam Senjaya (2011: 1) berpendapat bahwa prestasi adalah penilaian pendidikan tentang perkembangan dan kemajuan siswa berkenaan dengan penguasaan bahan pelajaran yang disajikan kepada siswa. Dari beberapa pengertian di atas, maka prestasi adalah hasil dari suatu kegiatan seseorang atau kelompok yang telah dikerjakan, diciptakan dan menyenagkan hati yang diperoleh dengan jalan bekerja. Selanjutnya, untuk memahami pengertian tentang belajar berikut dikemukakan beberapa pengertian belajar. Menurut Slameto, dalam Senjaya (2011: 2) bahwa belajar ialah suatu usaha yang dilakukan seseorang untuk memperoleh suatu perubahan tingkah laku yang baru secara keseluruhan, sebagai hasil pengalamannya sendiri dalam interaksi dengan lingkungannya. Muhibbinsyah, dalam Senjaya (2011: 2) bahwa belajar adalah tahapan perubahan seluruh tingkah lakuindividu yang relatif menetap sebagai hasil pengalaman dan interaksi dengan lingkungan yang melibatkan proses kognitif.

Model pembelajaran kooperatif Type Picture and Picture menurut para ahli dapat meningkatkan hasil belajar dan keaktivan peserta didik sebagaimana yang dikemukaan oleh Dewi Rima Ratri (2003) menyatakan Picture and Picture adalah suatu model pembelajaran dengan menggunaan media gambar. Dalam oprasionalnya gambar-gambar dipasangkan satu sama lain atau bisa jadi di urutkan menjadi urutan yang logis. Model Pembelajaran Picture and Picture ini merupakan salah satu bentuk model pembelajaran kooperatif. Model pembelajaran kooperatif merupakan suatu model pembelajaran yang mengutamakan adanya kelompok-kelompok. Pembelajaran kooperatif adalah pembelajaran yang secara sadar dan sistematis mengembangkan interaksi 
yang saling asah, silih asih, dan silih asuh.

\section{A. Rumusan Masalah}

Berdasarkan latar belakang yang telah diuraikan, rumusan permasalahan pada penelitian ini adalah sebagai berikut.

1) Apakah model pembelajaran kooperatif Type Picture and Picture dapat meningkatkan hasil belajar peserta didik tentang medan magnet di Kelas XI EB semester 4 Tahun Pelajaran 21052016 SMK Negeri 2 Kota Bogor?

2) Bagsaimana proses peningkatkan hasil belajar peserta didik tentang medan magnet sebelum dan sesudah menggunakan model pembelajaran kooperatif Type Picture and Picture di Kelas XI EB semester 4 Tahun Pelajaran 2105-2016 SMK Negeri 2 Kota Bogor?

3) Berapa besar peningkatan hasil belajar peserta didik tentang medan magnet setelah menggunakan menggunakan model pembelajaran kooperatif Type Picture and Picture di Kelas XI EB semester 4 Tahun
Pelajaran 2105-2016 SMK

Negeri 2 Kota Bogor?

\section{B. Tujuan Penelitian}

Berdasarkan atas perumusan masalah di atas tujuan penelitian ini adalah sebagai berikut.

1) Untuk mengetahui model pembelajaran kooperatif Type Picture and Picture dapat meningkatkan hasil belajar peserta didik tentang medan magnet di Kelas XI EB semester 4 Tahun Pelajaran 2105-2016 SMK Negeri 2 Kota Bogor.

2) Untuk mendeskripsikan proses peningkatkan hasil belajar peserta didik tentang medan magnet sebelum dan sesudah menggunakan model pembelajaran kooperatif Type Picture and Picture di Kelas XI EB semester 4 Tahun Pelajaran 2105-2016 SMK Negeri 2 Kota Bogor.

3) Untuk mengukur besarnya peningkatan hasil belajar peserta didik tentang medan magnet setelah menggunakan menggunakan model pembelajaran kooperatif Type Picture and Picture di Kelas XI 
EB semester 4 Tahun Pelajaran 2105-2016 SMK Negeri 2 Kota Bogor.

\section{METODOLOGI}

\section{A. Setting Penelitian}

Penelitian ini dilaksanakan pada Semester 4 tahun pelajaran 2015-2016 dari bulan Januari sampai dengan bulan Juni 2016. Alasan pelaksanakan pada Semester 4 karena tentang Medan Magnet harus diajarkan kepada peserta didik kelas XI EB berdasarkan kurikulum 2013.

\section{B. Subyek Penelitian}

Penelitian ini dilaksanakan Di Kelas XI EB Semester 4 Tahun Pelajaran 2015-2016 SMK Negeri 2 Kota Bogor. Ketika guru mengajar mata pelajaran Fisika tentang Medan Magnet . KKM telah ditentukan 75 , setelah dianalisis peserta didik yang mendapatkan nilai diatas KKM 11 orang (39\%) di bawah KKM 25 orang (61\%) dengan niai rata-rata kelas 64 . Padahal tentang Medan Magnet bahasannya cukup banyak/luas, jika kondisi tersebut tidak diatasi maka makna dan tujuan pembelajaran ini kurang tercapai.
Penelitian ini akan dilaksanakan pada Semester 4 tahun pelajaran 2015-2016, pada kelas XI EB tentang Medan Magnet pada Semester 4 antara bulan April - Mei 2016. Adapun subyek penelitian ini adalah peserta didik kelas XI EB SMK Negeri 2 Kota Bogor berjumlah 28 orang terdiri dari laki-laki 16 orang dan perempuan 12 orang.

\section{Instrumen Penelitian}

Untuk mendapatkan data yang diperlukan oleh penulis, digunakan instrumen pengumpulan data sebagai berikut:

\section{1) Tes Uji Kompetensi}

Tes uji kompetensi digunakan untuk memperoleh data mengenai hasil belajar peserta didik yang dilaksanakan setelah pembelajaran berlangsung yaitu dengan menggunakan Model pembelajaran kooperatif Type Picture and Picture dalam tentang Medan Magnet. Tes berupa tes tertulis dengan jumlah soal 25 yang bentuk soalnya pilihan ganda 20 soal dan isian 5 soal baik siklus I maupun siklus II. Perangkat uji kompetensi yang terdiri dari master soal, kunci jawaban dan pedoman penelitian di validasi oleh tim ahli, tim ahli terdiri dari Kepala SMK Negeri 2 Bogor dan Pengawas Binaan. 
2) Lembar Observasi

Lembar observasi disusun untuk memperoleh gambaran langsung tentang kondisi pelaksanaan model pembelajaran kooperatif Type Picture and Picture di kelas. Observasi tindakan dilakukan oleh guru lain yang bertindak sebagai observer adalah Dra. $\mathrm{Hj}$. Wahyuningsih beliau guru kelas XI SMK Negeri 2 Kota Bogor. Lembar observasi disusun untuk mengamati peneliti dalam melaksanakan tindakan kelas, kondisi kelas dan keaktifan peserta didik dalam proses pembelajaran.

\section{Prosedur Penelitian}

Penelitian tindakan kelas berkesinambungan. Tahap-tahap tersebut yaitu: (1) Guru menyampaikan tujuan pembelajaran atau kompetensi yang ingin dicapai, (2) Memberikan materi pengantar sebelum kegiatan, (3) Guru menyediakan gambar-gambar yang akan digunakan, (4) Guru menunjuk siswa secara bergilir untuk mengurutkan atau memasangkan gambar-gambar yang ada, (5) Guru memberikan pertanyaan mengenai alasan siswa dalam menentukan urutan gambar, (6) Dari alasan tersebut guru akan mengembangkan materi, (7) Siswa diajak untuk menyimpulkan/merangkum materi. Secara visual, tatap-tahap tersebut dapat dilihat pada Gambar 1 berikut ini.

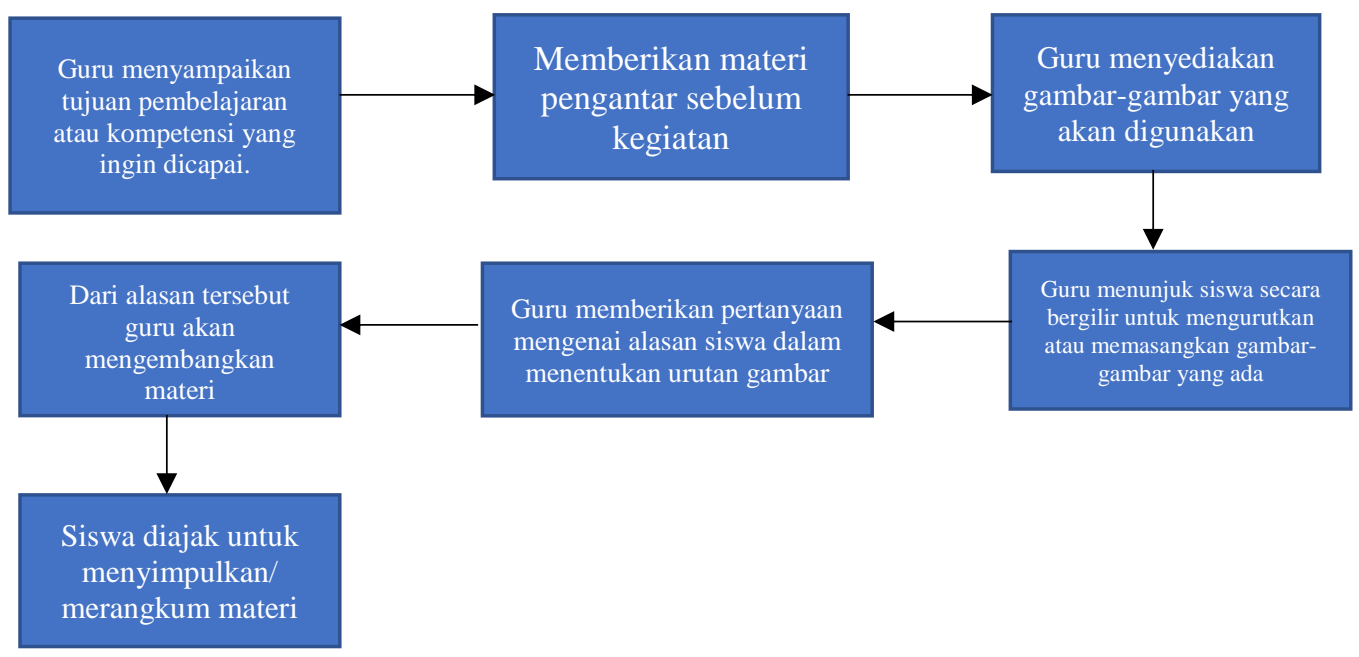

Gambar 1. Alur Pelaksanaan Tindakan dalam Penelitian Tindakan Kelas

merupakan proses pengkajian melalui sistem yang berdaur ulang dari berbagai kegiatan pembelajaran yang terdiri atas empat tahap yang saling terkait dan

\section{E. Pengolahan Data}

Langkah-langkah pengolahan data dalam penelitian ini adalah sebagai berikut: 
1) Mengolah data yang terkumpul seperti: untuk melihat besarnya

a. Data aktivitas peserta didik sewaktu proses pembelajaran yaitu dari lembar observasi.

b. Data berupa nilai yang diperoleh dari hasil uji kompetensi.

c. Data lembar observasi pengamat.

2) Menyeleksi data:

Langkah ini dilakukan untuk mengetahui apakah data yang terkumpul dapat diolah atau tidak.

\section{F. Analisis Data}

Analisis data yang digunakan dalam penelitian ini yaitu teknik kuantitatif yang berupa perhitungan dan teknik kualitatif yang berupa uraian.

3) Mengklarifikasikan dan mentabulasikan data

Langkah klarifikasi data dilakukan untuk mengelompokkan data sesuai dengan alternatif jawaban yang tertera dalam kuesioner.

Sedangkan langkah

mentabulasikan data

dilakukan untuk memperoleh gambaran mengenai jumlah frekuensi dan kecenderungannya dalam kuesioner.

4) Menghitung Persentase persentase dari setiap alternatif jawaban pada setiap pertanyaan sehingga data yang diperoleh data dianalisa.

5) Menyimpulkan hasil penelitian setelah hasil dianalisis. bila memenuhi persyaratan maka data tersebut ditabulasikan dalam tabel yang telah siap untuk pengolahan. Setelah dicek kebenarannya kemudian dihitung persentasenya.

\section{HASIL PENELITIAN DAN} PEMBAHASAN

\section{A. Deskripsi Kondisi Awal}

Sebelum melakukan tindakan dalam penelitian, peneliti melakukan observasi awal di kelas. Hasil observasi menunjukkan bahwa ketika guru mengajar mata pelajaran Fisika tentang medan magnet adalah rata-ratanya 70 sedangkan KKM yang ditentukan 75 . 
Peserta didik yang mendapatkan nilai di atas KKM hanya 11 orang $(30,5 \%)$ sedangkan peserta didik yang mendapat nilai dibawah KKM 25 orang $(69,44 \%)$.

Padahal materi Medan Magnet bahasannya cukup banyak/luas, maka diputuskan untuk menggunakan model pembelajaran Type Picture and Picture pada mata pelajaran Fisika dalam materi Medan Magnet.

Pembelajaran dimulai dengan mengadakan tes awal di kelas XI EB untuk mengetahui kemampuan awal peserta didik pada materi Medan Magnet Nilai tes awal dijadikan acuan untuk mengetahui hasil belajar peserta didik kelas XI EB setelah digunakan model pembelajaran Type Picture and Picture. Soal-soal tes awal berupa materi yang berhubungan dengan materi yang akan diajarkan yaitu Medan Magnet. Perolehan nilai tes awal ini akan dijadikan acuan untuk mengetahui peningkatan hasil belajar siswa setelah menggunakan model pembelajaran Type Picture and Picture. Berikut disajikan data hasil belajar siswa pada pra siklus.

Tabel 1. Data Hasil Belajar Peserta didik Pada Pra Siklus

\begin{tabular}{|c|l|c|c|}
\hline No. & $\begin{array}{c}\text { Nama Peserta } \\
\text { Didik }\end{array}$ & Nilai & Keterangan \\
\hline 1 & $\begin{array}{l}\text { Anggita } \\
\text { Wahyuningsih }\end{array}$ & 76 & Tuntas \\
\hline
\end{tabular}

\begin{tabular}{|c|c|c|c|}
\hline No. & $\begin{array}{c}\text { Nama Peserta } \\
\text { Didik }\end{array}$ & Nilai & Keterangan \\
\hline 2 & Ayu Amalia & 50 & $\begin{array}{l}\text { Belum } \\
\text { tuntas }\end{array}$ \\
\hline 3 & $\begin{array}{l}\text { Chintya Fausia } \\
\text { Rahmadani }\end{array}$ & 65 & $\begin{array}{l}\text { Belum } \\
\text { tuntas }\end{array}$ \\
\hline 4 & $\begin{array}{l}\text { Dea Novia } \\
\text { Eka Nanda }\end{array}$ & 70 & $\begin{array}{l}\text { Belum } \\
\text { tuntas }\end{array}$ \\
\hline 5 & $\begin{array}{ll}\text { Delfian } & \text { Jodi } \\
\text { Saputra } & \\
\end{array}$ & 75 & Tuntas \\
\hline 6 & Ferdiansyah & 67 & $\begin{array}{l}\text { Belum } \\
\text { tuntas }\end{array}$ \\
\hline 7 & $\begin{array}{l}\text { Indra } \\
\text { Saptarudin }\end{array}$ & 78 & Tuntas \\
\hline 8 & $\begin{array}{ll}\text { M. } & \text { Fariz } \\
\text { Yusuf } & \end{array}$ & 68 & $\begin{array}{l}\text { Belum } \\
\text { tuntas }\end{array}$ \\
\hline 9 & $\begin{array}{l}\text { Muhamad } \\
\text { Arie Shandy }\end{array}$ & 75 & Tuntas \\
\hline 10 & $\begin{array}{l}\text { Muhammad } \\
\text { Irfan } \\
\text { Juliansyah }\end{array}$ & 50 & $\begin{array}{l}\text { Belum } \\
\text { tuntas }\end{array}$ \\
\hline 11 & $\begin{array}{l}\text { Muhammad } \\
\text { Fauzan Malik }\end{array}$ & 56 & $\begin{array}{l}\text { Belum } \\
\text { tuntas }\end{array}$ \\
\hline 12 & $\begin{array}{l}\text { Muhammad } \\
\text { Alwan Fauzan }\end{array}$ & 75 & Tuntas \\
\hline 13 & $\begin{array}{l}\text { Muhammad } \\
\text { Ali }\end{array}$ & 67 & $\begin{array}{l}\text { Belum } \\
\text { tuntas }\end{array}$ \\
\hline 14 & $\begin{array}{l}\text { Nofia } \\
\text { Fitriansyah }\end{array}$ & 69 & $\begin{array}{l}\text { Belum } \\
\text { tuntas }\end{array}$ \\
\hline 15 & $\begin{array}{ll}\text { Prida } & \text { Dwi } \\
\text { Agustini } & \\
\end{array}$ & 70 & $\begin{array}{l}\text { Belum } \\
\text { tuntas }\end{array}$ \\
\hline 16 & Rika hamalimi & 77 & Tuntas \\
\hline 17 & $\begin{array}{ll}\text { Renaldi } & \text { Eka } \\
\text { Wahyudi } & \\
\end{array}$ & 78 & Tuntas \\
\hline 18 & Ryan Aulianus & 76 & Tuntas \\
\hline 19 & Ryan Amanda & 75 & Tuntas \\
\hline 20 & $\begin{array}{l}\text { Selviana } \\
\text { Widyasari }\end{array}$ & 63 & $\begin{array}{l}\text { Belum } \\
\text { tuntas }\end{array}$ \\
\hline 21 & Siti Azizah & 56 & $\begin{array}{l}\text { Belum } \\
\text { tuntas }\end{array}$ \\
\hline 22 & $\begin{array}{l}\text { Siti Adinda } \\
\text { Diyanti }\end{array}$ & 62 & $\begin{array}{l}\text { Belum } \\
\text { tuntas }\end{array}$ \\
\hline 23 & Sugiyono & 54 & $\begin{array}{l}\text { Belum } \\
\text { tuntas }\end{array}$ \\
\hline 24 & Tanti Herawati & 57 & $\begin{array}{l}\text { Belum } \\
\text { tuntas }\end{array}$ \\
\hline 25 & Veni Melinda & 62 & $\begin{array}{l}\text { Belum } \\
\text { tuntas }\end{array}$ \\
\hline 26 & $\begin{array}{ll}\text { Vicky } & \text { Nur } \\
\text { Rahayu } & \\
\end{array}$ & 76 & Tuntas \\
\hline 27 & $\begin{array}{l}\text { Willi } \\
\text { Ferdianto }\end{array}$ & 79 & Tuntas \\
\hline
\end{tabular}




\begin{tabular}{|l|l|c|l|}
\hline No. & $\begin{array}{l}\text { Nama Peserta } \\
\text { Didik }\end{array}$ & Nilai & Keterangan \\
\hline 28 & Yoga Febrian & 70 & $\begin{array}{c}\text { Belum } \\
\text { tuntas }\end{array}$ \\
\hline & Rata-rata & 64 & \\
\hline & Nilai Terendah & 50 & \\
\hline & Nilai Tertinggi & 79 & \\
\hline & $\begin{array}{l}\text { Jumlah yang } \\
\text { sudah tuntas }\end{array}$ & 11 & \\
\hline & $\begin{array}{l}\text { Jumlah yang } \\
\text { belum tuntas }\end{array}$ & 17 & \\
\hline & $\begin{array}{l}\text { Prosentase } \\
\text { Ketuntasan }\end{array}$ & $39 \%$ & \\
\hline
\end{tabular}

Jika digambarkan dalam bentuk grafik, maka data hasil belajar pada para siklus tersaji pada Gambar 2 berikut. yaitu 75. Hal ini memberikan gambaran bahwa hasil belajar peserta didik pada mata pelajaran Pendidikan Fisika masih tergolong rendah.

\section{B. Hasil Observasi Siklus I}

Dari hasil observasi siklus I, didapat bahwa dalam melaksanakan pembelajaran Fisika tentang Medan Magnet dengan menggunakan model pembelajaran Type Picture and Picture pada siklus I, guru telah menerapkannya sesuai dengan Rencana

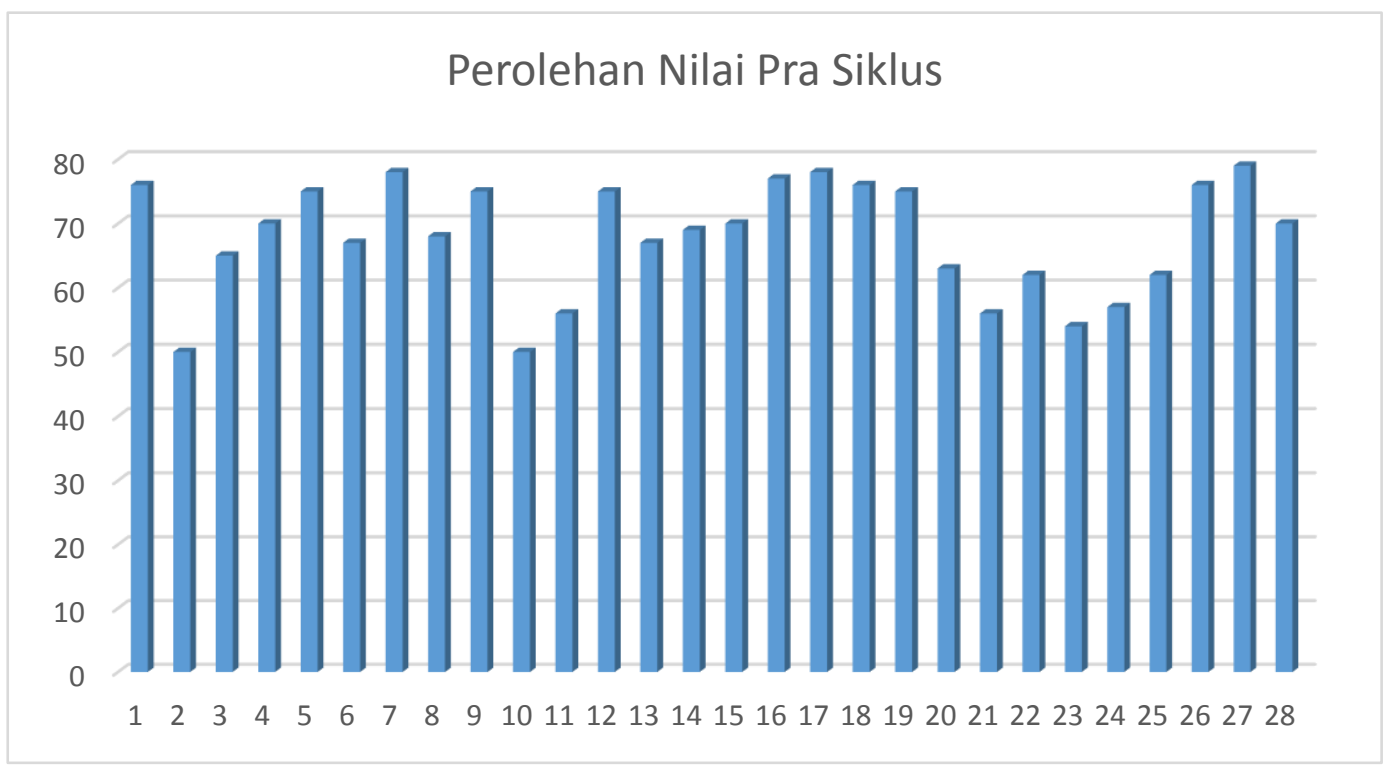

Gambar 2. Data Hasil Belajar Peserta Didik Pada Pra Siklus

Pelaksanaan Pembelajaran (RPP) yang

Berdasarkan Tabel 1 dan Gambar 2 terlihat bahwa peserta didik hanya memperoleh rata-rata 64 dengan nilai tertinggi 79 dan nilai terendah 50 . Peserta didik yang hasil belajarnya diatas KKM hanya 11 orang atau 39,29\% dari nilai KKM yang ditetapkan telah disiapkan. Berdasarkan hasil pengamatan yang dilakukan oleh observer, guru terlalu cepat dalam menjelaskan. Masalah lain yang di dapat dari pengamatan observer adalah pada saat guru menjelaskan materi, 
masih ada peserta didik yang kurang memperhatikan.

Data mengenai keaktifan peserta didik dapat diperoleh dengan menggunakan lembar observer seperti pada lampiran. Keaktifan peserta didik tersebut dapat dilihat dalam hal bertanya dan menjawab pertanyaan dari guru maupun antusiasnya dalam mengerjakan latihan pada saat proses pembelajaran berlangsung. Data mengenai keaktifan peserta didik pada siklus I dapat dilihat pada Tabel 2.

\section{Tabel 2. Data Mengenai Keaktifan Peserta didik Pada Siklus I}

\begin{tabular}{|c|c|c|c|c|}
\hline \multirow{2}{*}{$\begin{array}{l}\mathrm{N} \\
\mathrm{o}\end{array}$} & \multirow{2}{*}{$\begin{array}{c}\text { Nama Peserta } \\
\text { didik }\end{array}$} & \multicolumn{3}{|c|}{ Perhatian Peserta didik } \\
\hline & & $\mathrm{B}$ & $\mathrm{C}$ & $\mathrm{K}$ \\
\hline 1 & $\begin{array}{l}\text { Anggita } \\
\text { Wahyuningsih }\end{array}$ & $\sqrt{ }$ & & \\
\hline 2 & Ayu Amalia & & & $\sqrt{ }$ \\
\hline 3 & $\begin{array}{l}\text { Chintya Fausia } \\
\text { Rahmadani }\end{array}$ & & $\sqrt{ }$ & \\
\hline 4 & $\begin{array}{l}\text { Dea Novia Eka } \\
\text { Nanda }\end{array}$ & & $\sqrt{ }$ & \\
\hline 5 & $\begin{array}{lr}\text { Delfian } & \text { Jodi } \\
\text { Saputra } & \\
\end{array}$ & $\sqrt{ }$ & & \\
\hline 6 & Ferdiansyah & & $\sqrt{ }$ & \\
\hline 7 & $\begin{array}{l}\text { Indra } \\
\text { Saptarudin }\end{array}$ & $\sqrt{ }$ & & \\
\hline 8 & M. Fariz Yusuf & & & $\sqrt{ }$ \\
\hline 9 & $\begin{array}{l}\text { Muhamad Arie } \\
\text { Shandy }\end{array}$ & $\sqrt{ }$ & & \\
\hline 10 & $\begin{array}{l}\text { Muhammad } \\
\text { Irfan } \\
\text { Juliansyah }\end{array}$ & & & $\sqrt{ }$ \\
\hline 11 & $\begin{array}{l}\text { Muhammad } \\
\text { Fauzan Malik }\end{array}$ & & & $\sqrt{ }$ \\
\hline 12 & $\begin{array}{l}\text { Muhammad } \\
\text { Alwan Fauzan }\end{array}$ & $\sqrt{ }$ & & \\
\hline 13 & $\begin{array}{l}\text { Muhammad } \\
\text { Ali }\end{array}$ & & & $\sqrt{ }$ \\
\hline 14 & $\begin{array}{l}\text { Nofia } \\
\text { Fitriansyah }\end{array}$ & & $\sqrt{ }$ & \\
\hline 15 & $\begin{array}{ll}\text { Prida } & \text { Dwi } \\
\text { Agustini } & \\
\end{array}$ & & $\sqrt{ }$ & \\
\hline
\end{tabular}

\begin{tabular}{|c|l|c|c|c|}
\hline \multirow{2}{*}{$\begin{array}{c}\text { N } \\
\text { o. }\end{array}$} & \multirow{2}{*}{$\begin{array}{c}\text { Nama Peserta } \\
\text { didik }\end{array}$} & \multicolumn{2}{|c|}{ Perhatian Peserta didik } \\
\cline { 3 - 5 } & \multicolumn{2}{|c|}{ B } & C & K \\
\hline 16 & Rika hamalimi & $\sqrt{ }$ & & \\
\hline 17 & $\begin{array}{l}\text { Renaldi Eka } \\
\text { Wahyudi }\end{array}$ & $\sqrt{ }$ & & \\
\hline 18 & Ryan Aulianus & $\sqrt{ }$ & & \\
\hline 19 & Ryan Amanda & $\sqrt{ }$ & & \\
\hline 20 & $\begin{array}{l}\text { Selviana } \\
\text { Widyasari }\end{array}$ & & & $\sqrt{ }$ \\
\hline 21 & Siti Azizah & & $\sqrt{ }$ & \\
\hline 22 & $\begin{array}{l}\text { Siti Adinda } \\
\text { Diyanti }\end{array}$ & & $\sqrt{ }$ & \\
\hline 23 & Sugiyono & & $\sqrt{ }$ & \\
\hline 24 & Tanti Herawati & & $\sqrt{ }$ & \\
\hline 25 & Veni Melinda & & & \\
\hline 26 & $\begin{array}{l}\text { Vicky Nur } \\
\text { Rahayu }\end{array}$ & Willi Ferdianto & $\sqrt{ }$ & \\
\hline 28 & Yoga Febrian & & & \\
\hline & Jumlah & Prosentase (\%) & $\mathbf{3 9 , 2 9}$ & $\mathbf{3 2 , 1 5}$ \\
\hline
\end{tabular}

Jika digambarkan dalam bentuk grafik, maka data keaktifan siswa pada siklus 1 tersaji pada Gambar 3 berikut.

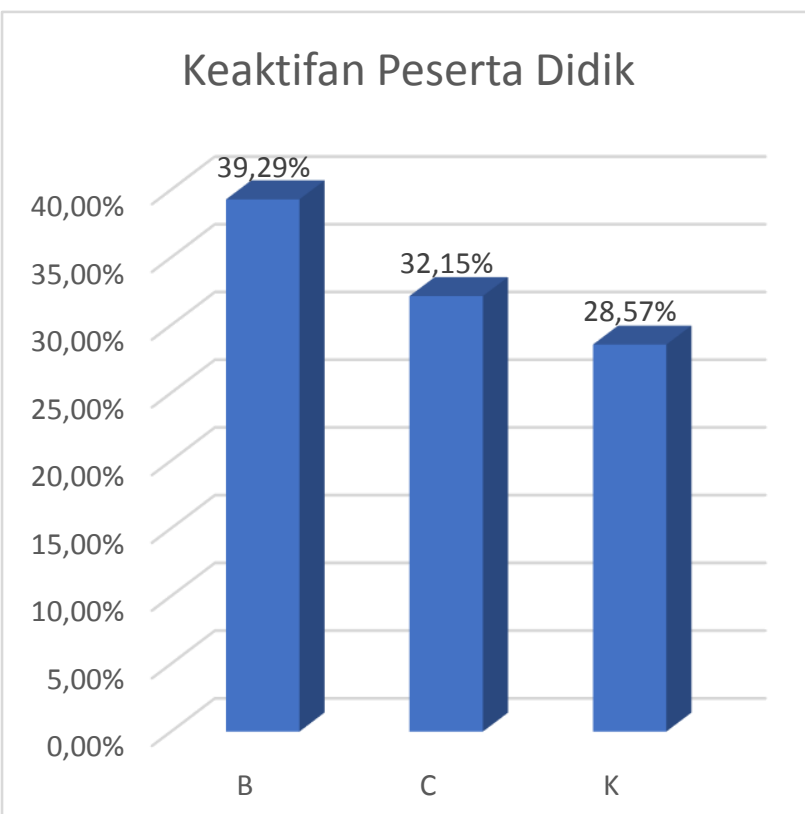

Gambar 3. Keaktifan Peserta Didik Pada Siklus 1 
Data pada tabel dan grafik mengenai aktifitas peserta didik pada siklus I menunjukkan bahwa 11 Orang $(39,29 \%)$ peserta didik baik dalam mengikuti KBM, 9 Orang $(32,15 \%)$ cukup mengikuti KBM dan 8 Orang $(28,57 \%)$ peserta didik kurang semangat mengikuti KBM.

Selanjutnya di bawah ini hasil pengamatan observer tentang aktivitas guru pada siklus I dapat dilihat pada Tabel 3.

\section{Tabel 3. Data Hasil Pengamatan}

Aktivitas Guru Pada Siklus I

\begin{tabular}{|c|c|c|c|c|}
\hline \multirow{2}{*}{$\begin{array}{l}\mathbf{N} \\
\mathbf{0}\end{array}$} & \multirow{2}{*}{ Aspek Yang Diamati } & \multicolumn{3}{|c|}{ Penilaian } \\
\hline & & $\begin{array}{c}\text { Bai } \\
\mathbf{k}\end{array}$ & $\begin{array}{c}\text { Cuk } \\
\text { up }\end{array}$ & $\begin{array}{c}\text { Kura } \\
\text { ng }\end{array}$ \\
\hline \multirow{3}{*}{1} & Pendahuluan & & & \\
\hline & $\begin{array}{ll}\text { a } & \begin{array}{l}\text { Memotivasi } \\
\text { peserta didik }\end{array} \\
\end{array}$ & & & $\sqrt{ }$ \\
\hline & b Apersepsi & $\sqrt{ }$ & & \\
\hline & Kegiatan Inti & & & \\
\hline & \begin{tabular}{ll} 
& \multicolumn{2}{l}{ Bahan-bahan } \\
& pembelajaran \\
a & yang disajikan \\
& sesuai dengan \\
& yang \\
& direncanakan
\end{tabular} & $\sqrt{ }$ & & \\
\hline & $\begin{array}{l}\text { Kesesuaian } \\
\text { pelaksanaan } \\
\text { model } \\
\text { bembelajaran } \\
\text { Type Picture and } \\
\text { Picture dengan } \\
\text { materi }\end{array}$ & $\sqrt{ }$ & & \\
\hline 2 & $\begin{array}{l}\text { Kemampuan } \\
\text { mengoptimalkan } \\
\text { pelaksanaan } \\
\text { c } \quad \text { model } \\
\text { pembelajaran } \\
\text { Type Picture and } \\
\text { Picture }\end{array}$ & & $\sqrt{ }$ & \\
\hline & $\begin{array}{l}\text { Antusiasme dalam } \\
\text { denanggapi } \\
\text { pertanyaan peserta } \\
\text { didik }\end{array}$ & & $\sqrt{ }$ & \\
\hline & $\begin{array}{l}\text { Membantu } \\
\text { meningkatkan } \\
\text { proses } \\
\text { pembelajaran } \\
\text { peserta didik }\end{array}$ & $\sqrt{ }$ & & \\
\hline
\end{tabular}

\begin{tabular}{|c|c|c|c|c|}
\hline \multirow{2}{*}{$\begin{array}{l}\mathbf{N} \\
\mathbf{o}\end{array}$} & \multirow[b]{2}{*}{ Aspek Yang Diamati } & \multicolumn{3}{|c|}{ Penilaian } \\
\hline & & $\begin{array}{c}\text { Bai } \\
\mathbf{k}\end{array}$ & $\begin{array}{c}\text { Cuk } \\
\text { up }\end{array}$ & $\begin{array}{c}\text { Kura } \\
\text { ng }\end{array}$ \\
\hline & \begin{tabular}{ll} 
& \multicolumn{2}{l}{ Mengarahkan } \\
peserta didik \\
$\mathrm{f} \quad$ \\
untuk \\
mengerjakan \\
latihan soal \\
\end{tabular} & & & $\sqrt{ }$ \\
\hline & g $\begin{array}{l}\text { Mengamati proses } \\
\text { belajar peserta } \\
\text { didik }\end{array}$ & $\sqrt{ }$ & & \\
\hline \multirow{3}{*}{3} & Penutup & & & \\
\hline & a Penilaian & $\sqrt{ }$ & & \\
\hline & b Refleksi & $\sqrt{ }$ & & \\
\hline 4 & Pengelolaan waktu & & $\sqrt{ }$ & \\
\hline 5 & $\begin{array}{ll}\text { Penggunaan } & \text { media } \\
\text { pembelajaran } & \\
\end{array}$ & & $\sqrt{ }$ & \\
\hline \multirow{3}{*}{6} & Suasana kelas & & & \\
\hline & a Semangat guru & & $\sqrt{ }$ & \\
\hline & b $\begin{array}{l}\text { Semangat peserta } \\
\text { didik }\end{array}$ & & $\sqrt{ }$ & \\
\hline 7 & Prosentase $(\%)$ & $\begin{array}{c}46,6 \\
7\end{array}$ & 40 & 13,33 \\
\hline
\end{tabular}

Jika digambarkan dalam bentuk grafik, maka data keaktivan guru pada siklus 1 tersaji pada Gambar berikut.

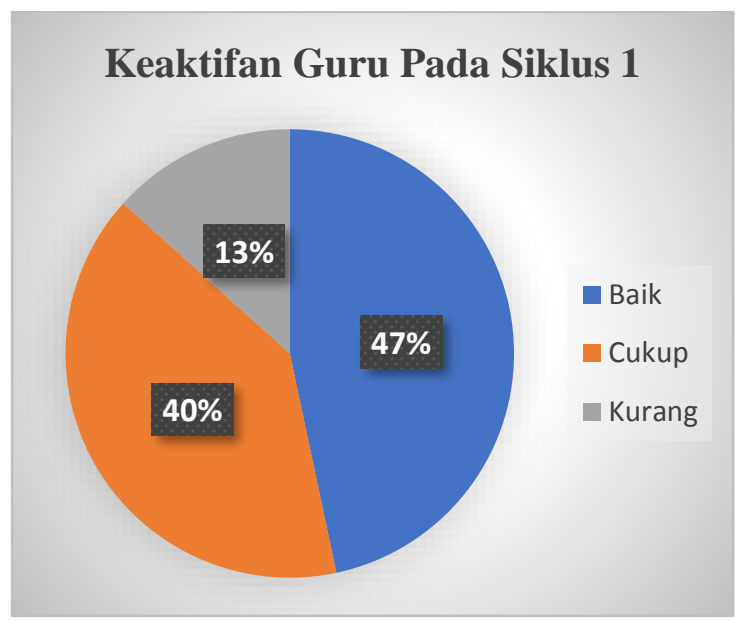

\section{Gambar 4. Keaktifan Guru Pada Siklus 1}

Data mengenai aktifitas guru pada siklus I menunjukkan bahwa kurang dari setengahnya $(46,67 \%)$ guru baik memotivasi peserta didik dalam 
mengikuti KBM, kurang setengahnya (40\%) guru cukup memotivasi peserta didik mengikuti KBM dan hanya sedikit $(13,33 \%)$ guru kurang memotivasi peserta didik dalam mengkuti KBM.

Untuk mengetahui besaran hasil belajar peserta didik, maka pada akhir siklus I dilakukan tes hasil belajar dan dapat dilihat pada Tabel 4 berikut.

\section{Tabel 4. Data Hasil Belajar Peserta} didik Pada Siklus I

\begin{tabular}{|c|c|c|c|}
\hline No. & $\begin{array}{c}\text { Nama } \\
\text { Peserta Didik }\end{array}$ & Nilai & Keterangan \\
\hline 1 & $\begin{array}{l}\text { Anggita } \\
\text { Wahyuningsih }\end{array}$ & 80 & Tuntas \\
\hline 2 & Ayu Amalia & 50 & $\begin{array}{l}\text { Belum } \\
\text { tuntas }\end{array}$ \\
\hline 3 & $\begin{array}{l}\text { Chintya } \\
\text { Fausia } \\
\text { Rahmadani } \\
\end{array}$ & 75 & Tuntas \\
\hline 4 & $\begin{array}{l}\text { Dea Novia } \\
\text { Eka Nanda }\end{array}$ & 75 & Tuntas \\
\hline 5 & $\begin{array}{ll}\text { Delfian } & \text { Jodi } \\
\text { Saputra } & \\
\end{array}$ & 75 & Tuntas \\
\hline 6 & Ferdiansyah & 60 & $\begin{array}{l}\text { Belum } \\
\text { tuntas }\end{array}$ \\
\hline 7 & $\begin{array}{l}\text { Indra } \\
\text { Saptarudin }\end{array}$ & 78 & Tuntas \\
\hline 8 & $\begin{array}{ll}\text { M. } & \text { Fariz } \\
\text { Yusuf } & \\
\end{array}$ & 76 & Tuntas \\
\hline 9 & $\begin{array}{l}\text { Muhamad } \\
\text { Arie Shandy }\end{array}$ & 75 & Tuntas \\
\hline 10 & $\begin{array}{l}\text { Muhammad } \\
\text { Irfan } \\
\text { Juliansyah }\end{array}$ & 75 & Tuntas \\
\hline 11 & $\begin{array}{l}\text { Muhammad } \\
\text { Fauzan Malik }\end{array}$ & 56 & $\begin{array}{l}\text { Belum } \\
\text { tuntas }\end{array}$ \\
\hline 12 & $\begin{array}{l}\text { Muhammad } \\
\text { Alwan Fauzan }\end{array}$ & 75 & Tuntas \\
\hline 13 & $\begin{array}{l}\text { Muhammad } \\
\text { Ali }\end{array}$ & 67 & $\begin{array}{l}\text { Belum } \\
\text { tuntas }\end{array}$ \\
\hline 14 & $\begin{array}{l}\text { Nofia } \\
\text { Fitriansyah }\end{array}$ & 78 & Tuntas \\
\hline 15 & $\begin{array}{ll}\text { Prida } & \text { Dwi } \\
\text { Agustini } & \end{array}$ & 75 & Tuntas \\
\hline 16 & $\begin{array}{l}\text { Rika } \\
\text { hamalimi }\end{array}$ & 77 & Tuntas \\
\hline 17 & $\begin{array}{l}\text { Renaldi Eka } \\
\text { Wahyudi }\end{array}$ & 78 & Tuntas \\
\hline
\end{tabular}

\begin{tabular}{|c|c|c|c|}
\hline No. & $\begin{array}{c}\text { Nama } \\
\text { Peserta Didik }\end{array}$ & Nilai & Keterangan \\
\hline 18 & $\begin{array}{l}\text { Ryan } \\
\text { Aulianus }\end{array}$ & 76 & Tuntas \\
\hline 19 & Ryan Amanda & 75 & Tuntas \\
\hline 20 & $\begin{array}{l}\text { Selviana } \\
\text { Widyasari }\end{array}$ & 65 & $\begin{array}{l}\text { Belum } \\
\text { tuntas }\end{array}$ \\
\hline 21 & Siti Azizah & 56 & $\begin{array}{l}\text { Belum } \\
\text { tuntas }\end{array}$ \\
\hline 22 & $\begin{array}{l}\text { Siti Adinda } \\
\text { Diyanti }\end{array}$ & 62 & $\begin{array}{l}\text { Belum } \\
\text { tuntas }\end{array}$ \\
\hline 23 & Sugiyono & 60 & $\begin{array}{l}\text { Belum } \\
\text { tuntas }\end{array}$ \\
\hline 24 & $\begin{array}{l}\text { Tanti } \\
\text { Herawati }\end{array}$ & 75 & Tuntas \\
\hline 25 & Veni Melinda & 62 & $\begin{array}{l}\text { Belum } \\
\text { tuntas }\end{array}$ \\
\hline 26 & $\begin{array}{ll}\text { Vicky } & \text { Nur } \\
\text { Rahayu } & \\
\end{array}$ & 76 & Tuntas \\
\hline 27 & $\begin{array}{l}\text { Willi } \\
\text { Ferdianto }\end{array}$ & 79 & Tuntas \\
\hline \multirow[t]{7}{*}{28} & Yoga Febrian & 70 & $\begin{array}{l}\text { Belum } \\
\text { tuntas }\end{array}$ \\
\hline & Rata-rata & 70,75 & \\
\hline & $\begin{array}{l}\text { Nilai } \\
\text { Terendah }\end{array}$ & 50 & \\
\hline & $\begin{array}{l}\text { Nilai } \\
\text { Tertinggi }\end{array}$ & 80 & \\
\hline & $\begin{array}{l}\text { Jumlah yang } \\
\text { sudah tuntas }\end{array}$ & 18 & \\
\hline & $\begin{array}{l}\text { Jumlah yang } \\
\text { belum tuntas }\end{array}$ & 10 & \\
\hline & $\begin{array}{l}\text { Prosentase } \\
\text { Ketuntasan }\end{array}$ & $64 \%$ & \\
\hline
\end{tabular}

Jika digambarkan dalam bentuk grafik, maka data hasil belajar pada siklus I tersaji pada Gambar 5 berikut.

Berdasarkan Tabel 4 dan Gambar 5 terlihat bahwa rata-rata nilai siswa 70,75 dengan nilai tertinggi 80 dan nilai terendah 50. Peserta didik yang hasil belajarnya di atas KKM ada 18 orang atau $64 \%$ dari nilai KKM dan peserta didik yang nilainya di bawah KKM ada 10 orang atau $36 \%$ dari KKM yang 
ditetapkan yaitu 75. Hal ini mengarahkan peserta didik dalam memberikan gambaran bahwa ada pengerjaan soal latihan.

peningkatan hasil belajar peserta didik dari pra siklus ke siklus I.
Data mengenai keaktifan pesertaa didik pada siklus II dapat dilihat pada Tabel 5.

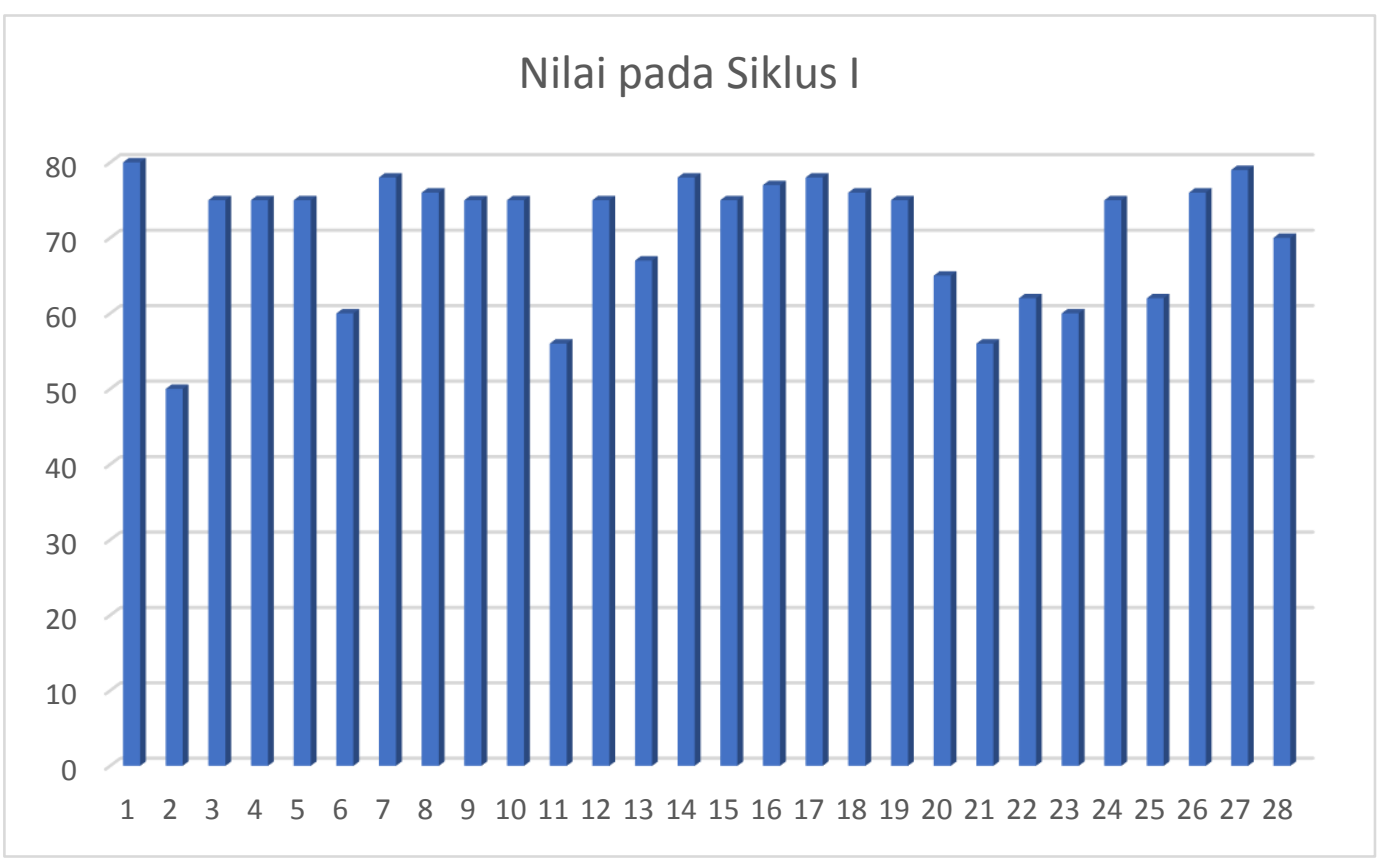

Gambar 5. Data Hasil Belajar Peserta Didik Pada Siklus I

\section{Hasil Observasi Siklus II}

Pada siklus II ini guru telah melakukan perbaikan-perbaikan.

Perbaikan dalam KBM tersebut yaitu guru lebih memotivasi peserta didik, sehingga lebih bersemangat dalam mengikuti KBM. Dengan semangat yang lebih tinggi, maka pembelajaran dapat berjalan lebih baik. Selain memotivasi peserts didik, guru juga memberikan lebih banyak kesempatan kepada peserta didik untuk menanyakan hal-hal yang belum jelas dan guru lebih
Tabel 5. Data Mengenai Keaktifan

Peserta Didik Pada Siklus II

\begin{tabular}{|c|l|c|c|c|}
\hline \multirow{2}{*}{$\begin{array}{c}\text { N } \\
\text { o. }\end{array}$} & \multirow{2}{*}{$\begin{array}{c}\text { Nama Peserta } \\
\text { didik }\end{array}$} & \multicolumn{3}{|c|}{$\begin{array}{c}\text { Perhatian Peserta } \\
\text { didik }\end{array}$} \\
\cline { 2 - 5 } 1 & $\begin{array}{l}\text { Anggita } \\
\text { Wahyuningsih }\end{array}$ & $\sqrt{ }$ & C & K \\
\hline 2 & Ayu Amalia & & $\sqrt{ }$ & \\
\hline 3 & $\begin{array}{l}\text { Chintya Fausia } \\
\text { Rahmadani }\end{array}$ & $\sqrt{ }$ & & \\
\hline 4 & $\begin{array}{l}\text { Dea Novia Eka } \\
\text { Nanda }\end{array}$ & $\sqrt{ }$ & & \\
\hline 5 & $\begin{array}{l}\text { Delfian Jodi } \\
\text { Saputra }\end{array}$ & $\sqrt{ }$ & & \\
\hline 6 & Ferdiansyah & $\sqrt{ }$ & & \\
\hline 7 & $\begin{array}{l}\text { Indra } \\
\text { Saptarudin }\end{array}$ & $\sqrt{ }$ & & \\
\hline 8 & M. Fariz Yusuf & & $\sqrt{ }$ & \\
\hline 9 & $\begin{array}{l}\text { Muhamad Arie } \\
\text { Shandy }\end{array}$ & $\sqrt{ }$ & & \\
\hline 10 & $\begin{array}{l}\text { Muhammad } \\
\text { Irfan Juliansyah }\end{array}$ & & $\sqrt{ }$ & \\
\hline
\end{tabular}




\begin{tabular}{|c|c|c|c|c|}
\hline \multirow{2}{*}{$\begin{array}{l}\mathrm{N} \\
\mathrm{o} .\end{array}$} & \multirow{2}{*}{$\begin{array}{c}\text { Nama Peserta } \\
\text { didik }\end{array}$} & \multicolumn{3}{|c|}{$\begin{array}{c}\text { Perhatian Peserta } \\
\text { didik }\end{array}$} \\
\hline & & $\mathrm{B}$ & $\mathrm{C}$ & $\mathrm{K}$ \\
\hline 11 & $\begin{array}{l}\text { Muhammad } \\
\text { Fauzan Malik }\end{array}$ & & $\sqrt{ }$ & \\
\hline 12 & $\begin{array}{l}\text { Muhammad } \\
\text { Alwan Fauzan }\end{array}$ & $\sqrt{ }$ & & \\
\hline 13 & Muhammad Ali & $\sqrt{ }$ & & \\
\hline 14 & $\begin{array}{l}\text { Nofia } \\
\text { Fitriansyah }\end{array}$ & $\sqrt{ }$ & & \\
\hline 15 & $\begin{array}{ll}\text { Prida } & \text { Dwi } \\
\text { Agustini } & \end{array}$ & $\sqrt{ }$ & & \\
\hline 16 & Rika hamalimi & $\sqrt{ }$ & & \\
\hline 17 & $\begin{array}{ll}\text { Renaldi } & \text { Eka } \\
\text { Wahyudi } & \\
\end{array}$ & & $\sqrt{ }$ & \\
\hline 18 & Ryan Aulianus & $\sqrt{ }$ & & \\
\hline 19 & Ryan Amanda & $\sqrt{ }$ & & \\
\hline 20 & $\begin{array}{l}\text { Selviana } \\
\text { Widyasari }\end{array}$ & & $\sqrt{ }$ & \\
\hline 21 & Siti Azizah & & $\sqrt{ }$ & \\
\hline 22 & $\begin{array}{ll}\text { Siti } & \text { Adinda } \\
\text { Diyanti } & \\
\end{array}$ & & $\sqrt{ }$ & \\
\hline 23 & Sugiyono & $\sqrt{ }$ & & \\
\hline 24 & Tanti Herawati & $\sqrt{ }$ & & \\
\hline 25 & Veni Melinda & $\sqrt{ }$ & & \\
\hline 26 & $\begin{array}{ll}\text { Vicky } & \text { Nur } \\
\text { Rahayu } & \\
\end{array}$ & $\sqrt{ }$ & & \\
\hline 27 & Willi Ferdianto & $\sqrt{ }$ & & \\
\hline 28 & Yoga Febrian & $\sqrt{ }$ & & \\
\hline & Jumlah & 22 & 6 & 0 \\
\hline & Prosentase $(\%)$ & $79 \%$ & $\begin{array}{l}21 \\
\%\end{array}$ & $0 \%$ \\
\hline
\end{tabular}

Jika digambarkan dalam bentuk grafik, maka data mengenai keaktrivan siswa pada siklus II tersaji pada Gambar 6.

Data mengenai aktifitas peserta didik pada siklus II menunjukkan bahwa hampir seluruh (79\%) peserta didik termotivasi dalam mengikuti KBM dan hanya sebagian kecil (21\%) peserta didik cukup termotivasi mengikuti KBM.

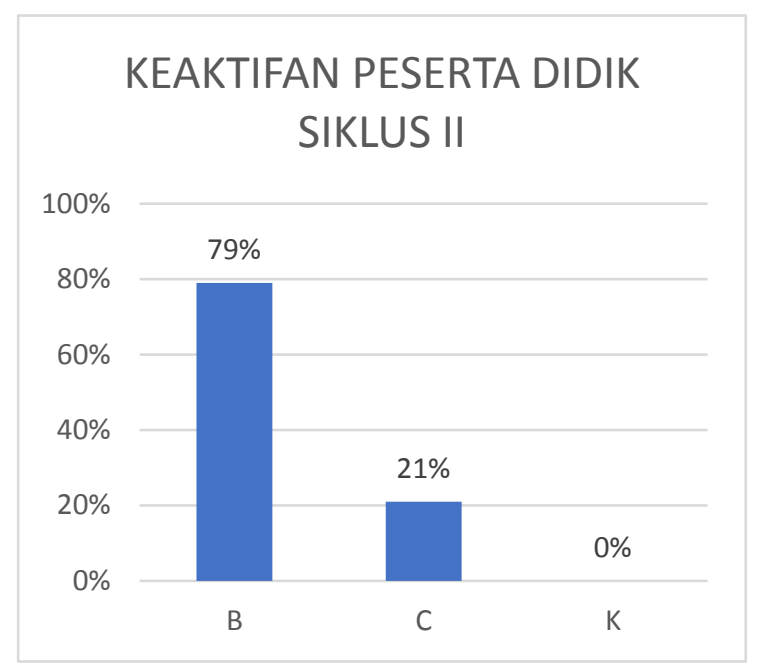

\section{Gambar 6. Keaktifan Peserta Didik Pada Siklus II}

Selanjutnya di bawah ini hasil pengamatan observer tentang aktivitas guru pada siklus II dapat dilihat pada Tabel 6.

Tabel 6. Data Hasil Pengamatan Aktivitas Guru Pada Siklus II

\begin{tabular}{|c|c|c|c|c|}
\hline \multirow{2}{*}{ No } & \multirow{2}{*}{$\begin{array}{l}\text { Aspek Yang } \\
\text { Diamati }\end{array}$} & \multicolumn{3}{|c|}{ Penilaian } \\
\hline & & Baik & Cukup & Kurang \\
\hline \multirow{6}{*}{1} & Pendahuluan & & & \\
\hline & $\begin{array}{ll}\text { a } & \begin{array}{l}\text { Memotivasi } \\
\text { peserta didik }\end{array} \\
\end{array}$ & $\sqrt{ }$ & & \\
\hline & b Apersepsi & $\sqrt{ }$ & & \\
\hline & Kegiatan Inti & & & \\
\hline & $\begin{array}{ll} & \text { Bahan-bahan } \\
& \text { pembelajaran } \\
\text { a } & \text { yang disajikan } \\
& \text { sesuai dengan } \\
& \text { yang } \\
& \text { direncanakan } \\
\end{array}$ & $\sqrt{ }$ & & \\
\hline & $\begin{array}{ll} & \text { Kesesuaian } \\
\text { pelaksanaan } \\
\text { model } \\
\text { bembelajaran } \\
\text { pype Picture and } \\
\text { Ticture dengan } \\
\text { materi } \\
\end{array}$ & $\sqrt{ }$ & & \\
\hline 2 & $\begin{array}{ll} & \text { Kemampuan } \\
& \text { mengoptimalkan } \\
\mathrm{c} & \text { pelaksanaan } \\
\text { model } \\
\text { pembelajaran }\end{array}$ & $\sqrt{ }$ & & \\
\hline
\end{tabular}




\begin{tabular}{|c|c|c|c|c|}
\hline \multirow{2}{*}{ No } & \multirow{2}{*}{$\begin{array}{l}\text { Aspek Yang } \\
\text { Diamati }\end{array}$} & \multicolumn{3}{|c|}{ Penilaian } \\
\hline & & Baik & Cukup & Kurang \\
\hline & $\begin{array}{l}\text { Type Picture and } \\
\text { Picture }\end{array}$ & & & \\
\hline & $\begin{array}{ll} & \begin{array}{l}\text { Antusiasme } \\
\text { dalam }\end{array} \\
\text { d } & \begin{array}{l}\text { menanggapi } \\
\text { pertanyaan }\end{array} \\
\text { peserta didik } \\
\text { Membantu } \\
\text { meningkatkan } \\
\text { e } \\
\text { proses } \\
\text { pembelajaran } \\
\text { peserta didik } \\
\end{array}$ & $\sqrt{ }$ & & \\
\hline & \begin{tabular}{ll} 
& \multicolumn{2}{l}{ Mengarahkan } \\
peserta didik \\
$\mathrm{f} \quad$ \\
untuk \\
mengerjakan \\
latihan soal \\
\end{tabular} & $\sqrt{ }$ & & \\
\hline & $\begin{array}{ll} & \begin{array}{l}\text { Mengamati } \\
\text { proses belajar } \\
\text { peserta didik }\end{array} \\
\end{array}$ & $\sqrt{ }$ & & \\
\hline \multirow{3}{*}{3} & Penutup & & & \\
\hline & a $\quad$ Penilaian & $\sqrt{ }$ & & \\
\hline & b Refleksi & $\sqrt{ }$ & & \\
\hline 4 & Pengelolaan waktu & $\sqrt{ }$ & & \\
\hline \multirow[t]{2}{*}{5} & $\begin{array}{ll}\begin{array}{l}\text { Penggunaan } \\
\text { pembelajaran }\end{array} & \text { media } \\
\end{array}$ & $\sqrt{ }$ & & \\
\hline & Suasana kelas & & & \\
\hline \multirow[t]{2}{*}{6} & a Semangat guru & $\sqrt{ }$ & & \\
\hline & $\begin{array}{ll}\mathrm{b} & \begin{array}{l}\text { Semangat } \\
\text { peserta didik }\end{array} \\
\end{array}$ & $\sqrt{ }$ & & \\
\hline 7 & Prosentase (\%) & $100 \%$ & $0 \%$ & $0 \%$ \\
\hline
\end{tabular}

Jika digambarkan dalam bentuk grafik, maka data aktivitas guru pada siklus II tersaji pada Gambar 7.

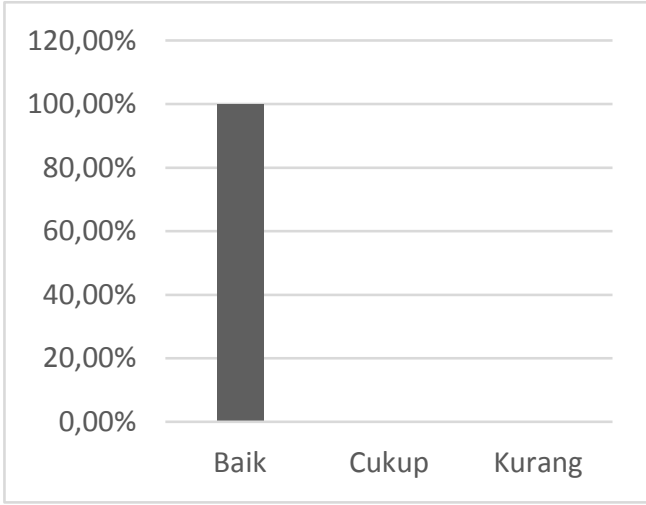

Gambar 7. Hasil Pengamatan Aktivitas Guru Pada Siklus II
Data mengenai aktifitas guru pada siklus II menunjukkan bahwa $100 \%$ guru dapat motivasi peserta didik, bahan-bahan yang disajikan sesuai dengan rencana dan penggunaan model pembelajaran Type Picture and Picture sesuai dengan yang direncanakan.

Untuk mengetahui besaran hasil belajar peserta didik, maka pada akhir siklus II dilakukan tes dengan hasil belajar dapat dilihat pada Tabel 7 berikut.

Tabel 7. Data Hasil Belajar Peserta Didik Pada Siklus II

\begin{tabular}{|c|c|c|c|}
\hline No. & $\begin{array}{c}\text { Nama Peserta } \\
\text { Didik }\end{array}$ & Nilai & Keterangan \\
\hline 1 & $\begin{array}{l}\text { Anggita } \\
\text { Wahyuningsih }\end{array}$ & 95 & Tuntas \\
\hline 2 & Ayu Amalia & 88 & Tuntas \\
\hline 3 & $\begin{array}{l}\text { Chintya Fausia } \\
\text { Rahmadani }\end{array}$ & 87 & Tuntas \\
\hline 4 & $\begin{array}{l}\text { Dea Novia Eka } \\
\text { Nanda }\end{array}$ & 87 & Tuntas \\
\hline 5 & $\begin{array}{ll}\text { Delfian } & \text { Jodi } \\
\text { Saputra } & \\
\end{array}$ & 87 & Tuntas \\
\hline 6 & Ferdiansyah & 80 & Tuntas \\
\hline 7 & Indra Saptarudin & 90 & Tuntas \\
\hline 8 & M. Fariz Yusuf & 78 & Tuntas \\
\hline 9 & $\begin{array}{ll}\text { Muhamad } & \text { Arie } \\
\text { Shandy } & \\
\end{array}$ & 85 & Tuntas \\
\hline 10 & $\begin{array}{l}\text { Muhammad Irfan } \\
\text { Juliansyah }\end{array}$ & 78 & Tuntas \\
\hline 11 & $\begin{array}{l}\text { Muhammad } \\
\text { Fauzan Malik }\end{array}$ & 78 & Tuntas \\
\hline 12 & $\begin{array}{l}\text { Muhammad } \\
\text { Alwan Fauzan }\end{array}$ & 85 & Tuntas \\
\hline 13 & Muhammad Ali & 83 & Tuntas \\
\hline 14 & Nofia Fitriansyah & 83 & Tuntas \\
\hline 15 & $\begin{array}{ll}\text { Prida } & \text { Dwi } \\
\text { Agustini } & \\
\end{array}$ & 85 & Tuntas \\
\hline 16 & Rika hamalimi & 84 & Tuntas \\
\hline 17 & $\begin{array}{ll}\text { Renaldi } & \text { Eka } \\
\text { Wahyudi } & \\
\end{array}$ & 78 & Tuntas \\
\hline 18 & Ryan Aulianus & 80 & Tuntas \\
\hline
\end{tabular}




\begin{tabular}{|c|c|c|c|}
\hline No. & $\begin{array}{c}\text { Nama Peserta } \\
\text { Didik }\end{array}$ & Nilai & Keterangan \\
\hline 19 & Ryan Amanda & 85 & Tuntas \\
\hline 20 & $\begin{array}{l}\text { Selviana } \\
\text { Widyasari }\end{array}$ & 79 & Tuntas \\
\hline 21 & Siti Azizah & 75 & Tuntas \\
\hline 22 & $\begin{array}{ll}\text { Siti } & \text { Adinda } \\
\text { Diyanti } & \\
\end{array}$ & 75 & Tuntas \\
\hline 23 & Sugiyono & 79 & Tuntas \\
\hline 24 & Tanti Herawati & 80 & Tuntas \\
\hline 25 & Veni Melinda & 83 & Tuntas \\
\hline 26 & $\begin{array}{ll}\text { Vicky } & \text { Nur } \\
\text { Rahayu } & \\
\end{array}$ & 80 & Tuntas \\
\hline 27 & Willi Ferdianto & 84 & Tuntas \\
\hline \multirow[t]{7}{*}{28} & Yoga Febrian & 87 & Tuntas \\
\hline & Rata-rata & 83 & \\
\hline & Nilai Terendah & 75 & \\
\hline & Nilai Tertinggi & 95 & \\
\hline & $\begin{array}{l}\text { Jumlah yang } \\
\text { sudah tuntas }\end{array}$ & 28 & \\
\hline & $\begin{array}{l}\text { Jumlah yang } \\
\text { belum tuntas }\end{array}$ & 0 & \\
\hline & $\begin{array}{l}\text { Prosentase } \\
\text { Ketuntasan }\end{array}$ & $100 \%$ & \\
\hline
\end{tabular}

Jika digambarkan dalam bentuk

grafik, maka data hasil belajar pada siklus II tersaji pada Gambar 8. peserta didik 83 dengan nilai tertinggi 95 dan nilai terendah 75. Peserta didik yang hasil belajarnya di atas KKM ada 28 orang atau $100 \%$ dari nilai KKM yang ditetapkan yaitu 75. Hal ini memberikan gambaran bahwa ada peningkatan hasil belajar peserta didik dari siklus I ke siklus II.

\section{Pembahasan}

Dari hasil pembelajaran menggunakan model pembelajaran Type Picture and Picture dan jawaban soal-soal evaluasi yang diberikan, kemudian peneliti menggunakan jawaban-jawaban tersebut untuk mengetahui apakah pembelajaran Fisika menggunakan model

\section{Hasil Belajar pada Siklus II}

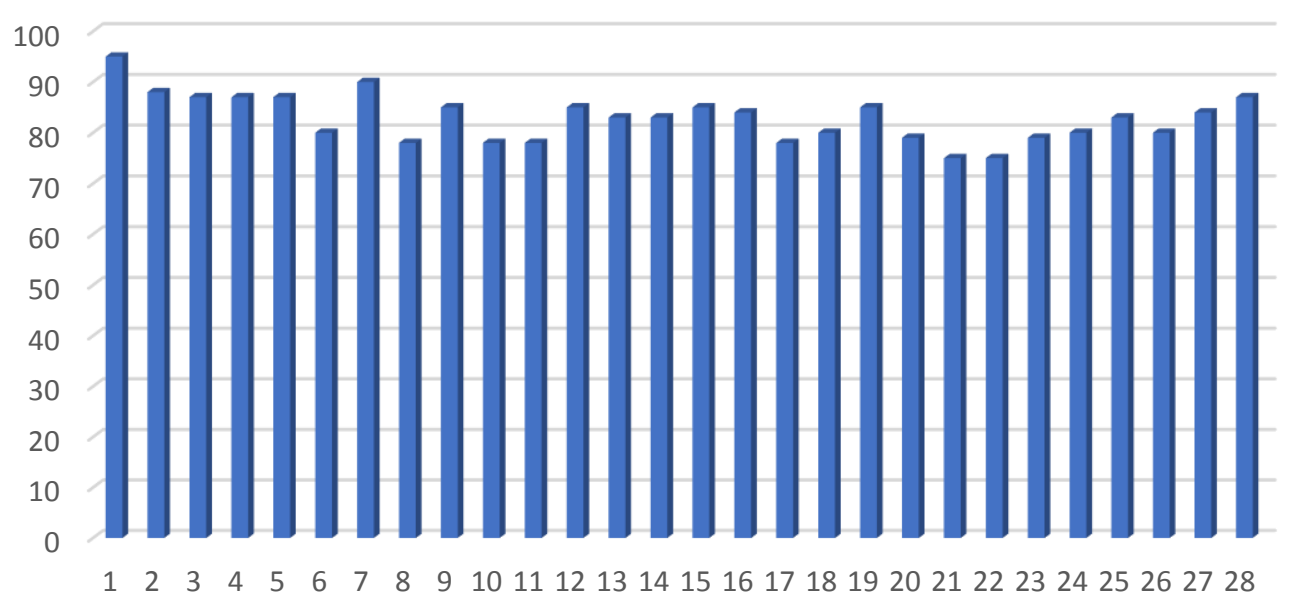

Gambar 8. Data Hasil Belajar Peserta Didik Pada Siklus II

pembelajaran Type Picture and Picture

Berdasarkan Tabel 7 dan tersebut dapat meningkatkan hasil Gambar 8 terlihat bahwa rata-rata nilai belajar siswa di kelas XI EB SMK 
Negeri 2 Kota Bogor. Berikut ini adalah data yang diperoleh dari hasil para siklus, siklus pertama, dan siklus kedua.

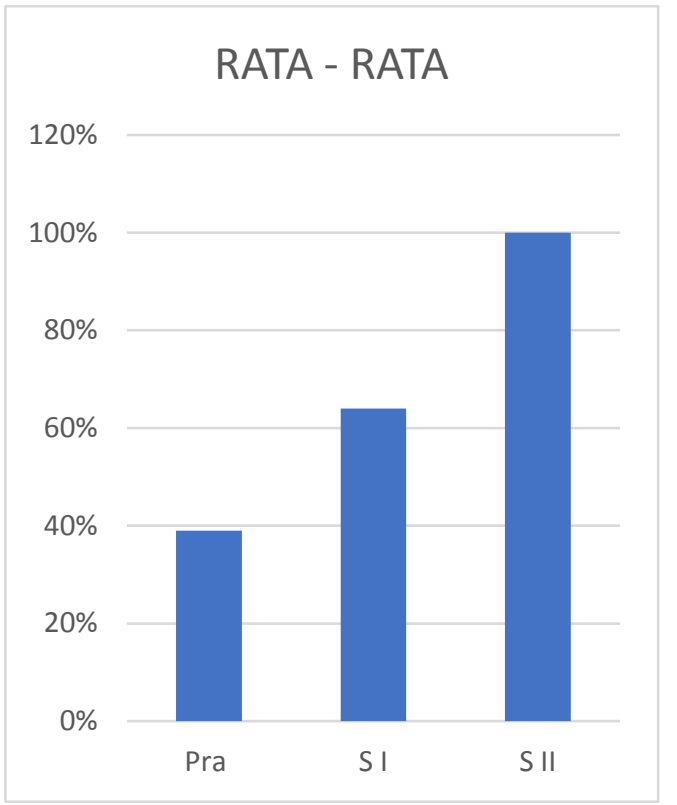

Gambar 9. Peningkatan Rata-Rata Nilai Peserta didik Tiap Siklus

Peningkatan rata-rata nilai peserta didik juga ditunjang oleh peningkatan nilai terendah dan nilai tertinggi peserta didik setiap siklus seperti yang tergambar pada Gambar 10.
Dari Gambar 10 di atas diperoleh bahwa nilai terendah pada pra siklus adalah 50 kemudian meningkat menjadi 50 pada siklus I dan meningkat lagi menjadi 75 pada siklus II. Selanjutnya nilai tertinggi pada pra siklus adalah 79 kemudian meningkat menjadi 80 pada siklus I dan meningkat lagi menjadi 95 pada siklus II. Hal ini membuktikan bahwa penggunaan model pembelajaran Type Picture and Picture cocok untuk diterapkan pada materi Medan Magnet.

Selain peningkatan rata-rata nilai peserta didik, penerapan model pembelajaran Type Picture and Picture juga dapat meningkatkan prosentase ketuntasan belajar peserta didik seperti yang tersaji pada Gambar 11 berikut.

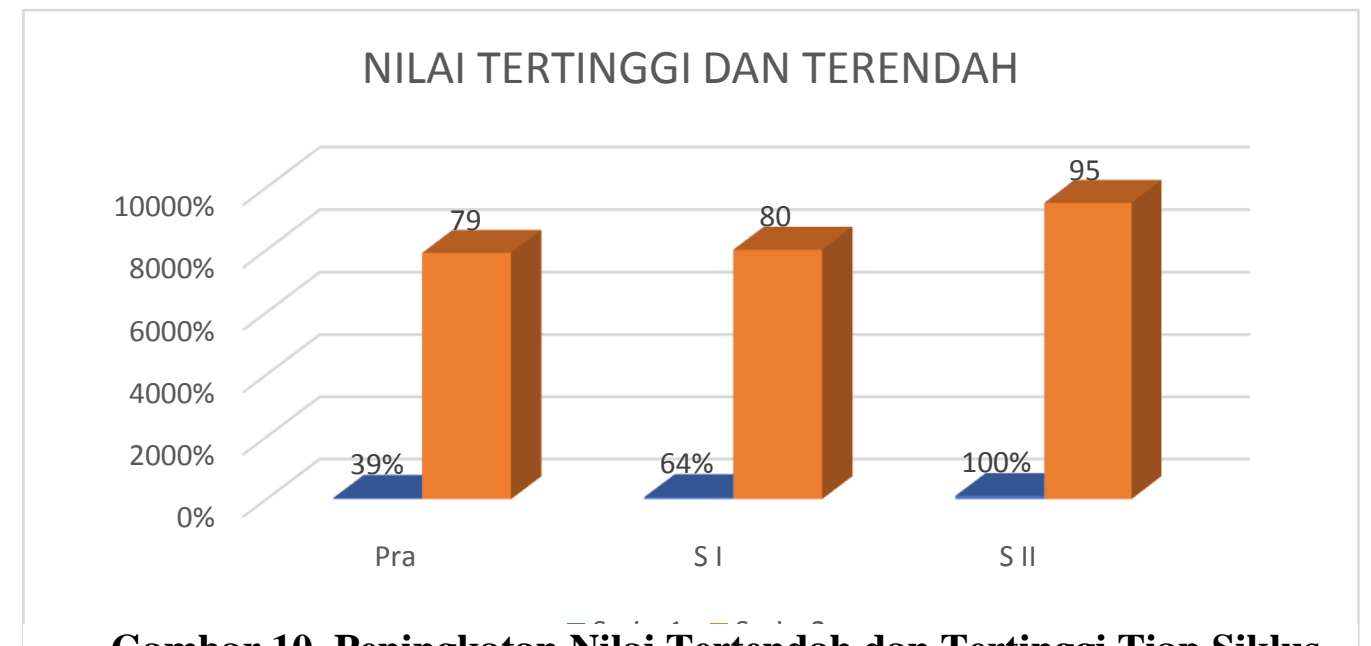

Gambar 10. Peningkatan Nilai Tertendảh dan Tertinggi Tiap Siklus 


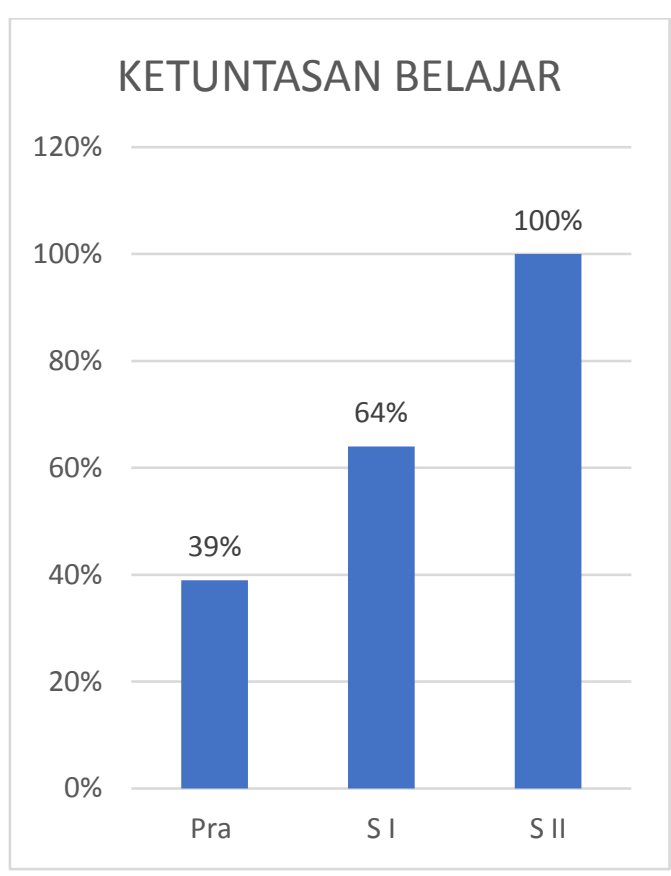

Gambar 11. Peningkatan Ketuntasan Belajar Peserta Didik Tiap Siklus

Dari Gambar 11 di atas diperoleh bahwa pada pra siklus hanya $39 \%$ atau 11 peserta didik yang nilainya di atas KKM yang ditetapkan, kemudian pada siklus I meningkat menjadi $64 \%$ atau 18 peserta didik yang nilainya di atas KKM selanjutnya pada siklus II menjadi $100 \%$ atau 28 peserta didik yang nilainya di atas KKM.

Data keaktifan peserta didik menunjukkan bahwa pada siklus I terdapat 39,29\% atau 11 peserta didik yang aktif, 32,15\% atau 9 peserta didik cukup aktif, dan $28,57 \%$ atau 8 peserta didik yang kurang aktif pada saat pembelajaran. Setelah guru memperbaiki hasil refleksi pada siklus I maka pada siklus II didapat $79 \%$ atau 22 peserta didik yang aktif pada saat pembelajaran dan $21 \%$ atau 6 peserta didik yang cukup aktif pada saat pembelajaran serta $0,00 \%$ atau tidak ada peserta didik yang tidak aktif pada saat pembelajaran. Dengan banyaknya peserta didik yang aktif pada saat pembelajaran menunjukkan bahwa guru saat menerangkan materi dengan menggunakan model pembelajaran Type Picture and Picture sudah berhasil melibatkan peserta didik dalam pembelajaran.

Data aktivitas guru menunjukkan bahwa pada siklus I secara umum sudah baik, namun ada beberapa komponen penilaian dari observer yang masih kurang yaitu kurang memotivasi peserta didik dan kurang mengarahkan peserta didik pada saat mengerjakan latihan soal sehingga semangat peserta didik pada siklus I secara umum masih kurang. Kekurangan-kekurangan pada siklus I ini kemudian diperbaiki pada siklus II dan aktivitas guru pada siklus II ini secara umum sudah baik.

Pembelajaran dengan menggunakan model pembelajaran Type Picture and Picture ini dapat meningkatkan hasil belajar peserta didik karena pembelajaran dengan 
menggunakan model pembelajaran Type Picture and Picture, peserta didik dalam belajar menjadi lebih aktif, kreatif, dan menyenangkan bagi peserta didik. Selain itu pula pembelajaran dilengkapi dengan menggunakan media pembelajaran audio visual menjadi lebih efektif. Akibatnya informasi yang diterima peserta didik akan diingat lebih lama.

Peningkatan hasil belajar yang signifikan antara sebelum dan sesudah belajar dengan menggunakan model pembelajaran Type Picture and Picture karena dalam pembelajaran dengan menggunakan model pembelajaran Type Picture and Picture, peserta didik merasa tidak belajar karena pembelajarannya menyenangkan bagi mereka. Hal tersebut membuat pelajaran menjadi melekat lebih lama dan baik secara langsung maupun tidak langsung, membuat peserta didik menjadi paham materi mengenai Medan Magnet.

\section{SIMPULAN}

Bedasarkan hasil penelitian yang telah dilakukan di SMK Negeri 2 Bogor pada peserta didik kelas XI EB Semester 4 tahun pelajaran 2015 - 2016 bahwa hasil belajar peserta didik sesudah menggunakan model pembelajaran Type Picture and Picture menunjukkan hasil yang memuaskan. Dari uraian pada bab sebelumnya, dapat diambil simpulan sebagai berikut:

1) Model pembelajaran Type Picture and Picture dapat meningkatan hasil belajar pesertsa didik pada tentang Medan Magnet di kelas XI EB SMK Negeri 2 Bogor dengan menggunakan model pembelajaran Type Picture and Picture

2) Penggunaan model pembelajaran Type Picture and Picture membuat peserta didik tidak bosan dan jenuh sebaliknya merasa senang sehingga aktivitas belajar mereka meningkat. Hal ini terbukti pada siklus I ada 55,55\% atau 20 peserta didik yang aktif, $22,22 \%$ atau 8 peserta didik yang cukup aktif dan 22,22\% atau 8 peserta didik yang kurang aktif pada saat pembelajaran. Setelah guru memperbaiki hasil refleksi pada siklus I maka pada siklus II didapat $77,77 \%$ atau 28 peserta didik aktif pada saat pembelajaran dan $22,22 \%$ atau 8 peserta tidak yang cukup aktif pada saat pembelajaran serta 
$0,00 \%$ atau tidak ada peserta didik yang tidak aktif pada saat pembelajaran. Hal tersebut berpengaruh terhadap hasil belajar yang dicapai peserta didik.

3) Hasil belajar mata pelajaran Fisika khususnya tentang Medan Magnet di kelas XI EB di SMK Negeri 2 Bogor sebelum menggunakan model pembelajaran Type Picture and Picture mempunyai nilai rata-rata 70. Pada saat pembelajaran diubah menggunakan model pembelajaran Type Picture and Picture, rata-rata hasil belajar peserta didik meningkat menjadi 75,56 pada siklus I dan 82,78 pada siklus II.

\section{DAFTAR PUSTAKA}

Arikunto, S. 2002. Prosedur Penelitian suatu Pendektan Praktek, Rineka Cipta, Jakarta.

Arikunto, S. 2005. Dasar-Dasar Evaluasi Pendidikan Bumi Aksara, Jakarta.

Armanto, D. 2008. Desain Intruksional Matematika, Pascasarjana Unimed, Medan.

Armawa, I.M. 2007. Meningkatkan Pemahaman Mahasiswa Dalam Aljabar Abstrak Melalui Pembelajaran Berdasarkan Teori APOS

(Online)
(http://www.sunan-ampeLac.id, diakses 23 Juli 2008).

Dubinsky, E. 2001. Using of Learning in College Mathematics Courses (online) (edd@mcs kent edu, diakses 23 Juli 2008).

Dubinsky, E. \& Donal, Mc. 2001. "APOS: A Construlctivist Theory of learning in Undergreduate Mathematics Education Research". Dalan D. Holton (ed). The Teaching ang learning of Mathematics as University level. Dordreacht Klumer Academic Publisher.

Daley, B.J. Shaw C.R. Balistrieri, 1'.: Glasenapp, K. Dan Piacentine L (1999), Concept maps: a strategy to teach and evaluate critical thinking, Journal of Nursing Education 38:42-47.

Erynck, G. 1991. "Mathematical Creativity". Dalam D Talb (ed). Advanched Mathematical Thingking. Dordrecht: Kluwer Academic Publishers.

Eitel, F.; Kanz, KG.; Honig, E. Dan Tesche, A., (2000), Do we face a fourth paradigm shift in medicine-algorithms in educations? Journal of Evaluation in Clinical Practica 6: 321-333.

GBPP, (2006), Garis-Garis Besar Program Pengajaran, Jurusan PMIPA STKIP Binjai.

Ghozali, Imam 2001. Analisis Multivariate Dengan Program SPSS, UNDIP, Semarang.

Gultom, S, 2006. Penggunaan Media Peta Konsep Untuk 
Meningkatkan Pembelajaran Dalam Bidang Kalkulus, FMIPA UNIMED. Medan.

Hanna, G. \& Janhke, N. 1996. "Proof and Proving". Dalam A.J. Bishopetal (ed). International Handlook of Mathematics Educations. Dordrecht: "Kluwer Academic Publisher.

Lipschutz. 1982. General Topology, Schum's outline series Mc GrawsHil International Book Company, Singapore.

McGaghie, WC.; McCrimmon, D.R.; Mitchell, G.; Thompson, J.A. dan Ravitch, MM. 2000. Quantitative concept mapping in pulmonary physiology: comparison of student and faculty knowledge structures., Advances in Physiology Education 23: 72-81.

Nakhleh, M.B. 1994. Chemical education research in the laboratory environment. How can research discover what student are learning, Journal of Chemical Education 71: 146. 